\title{
HALAL FOR ALL: GEO SPATIAL TOURISM OF HALAL FOOD STALLS IN MUSLIM MINORITY TOURIST DESTINATIONS
}

\author{
Luhung ACHMAD PERGUNA* \\ Universitas Negeri Malang, Faculty of Social Science, Sociology Department, Malang, Indonesia, e-mail: luhung.fis@um.ac.id
}

\author{
Listyo YUDHA IRAWAN
}

Universitas Negeri Malang, Faculty of Social Science, Geography Department, Malang, Indonesia, e-mail: listyo.fis@ um.ac.id

\author{
Elya KURNIAWATI \\ Universitas Negeri Malang, Faculty of Social Science, Sociology Department, Malang, Indonesia, e-mail: elya.kurniawati.fis@um.ac.id
}

\section{Sita TRIHARINI}

Universitas Negeri Malang, Faculty of Social Science, Sociology Department, Malang, Indonesia, e-mail: sitatriharini@gmail.com

Dhiyaulhaq SYAH PAHLEVI

Universitas Negeri Malang, Faculty of Social Science, Sociology Department, Malang, Indonesia, e-mail: dhylhqsap@gmail.com

\author{
Agus DWI FEBRIANTO
}

Universitas Negeri Malang, Faculty of Social Science, Geography Department, Malang, Indonesia, e-mail: august.febrianto@gmail.com

\begin{abstract}
Citation: Achmad Perguna, L., Yudha Irawan, L. Kurniawati, E., Triharini, S., Syah Pahlevi, D., \& Dwi Febrianto, A. (2021). HALAL FOR ALL: GEO SPATIAL TOURISM OF HALAL FOOD STALLS IN MUSLIM MINORITY TOURIST DESTINATIONS. GeoJournal of Tourism and Geosites, 36(2spl), 715-720. https://doi.org/10.30892/gtg.362spl20-702
\end{abstract}

\begin{abstract}
Denpasar, Bali is one of the popular tourist destinations in Indonesia, following its variety of unique cultures, local wisdom, and the majority of its society embraced Hinduism. However, the appeal shows the high increase of food stalls with halal labeling. Thus, this article aims to provide an overview of the growing and the development of halal food stalls within non-Muslim society along with its spatial distribution. The segmented growth of halal and non-halal food stalls continues to grow following Denpasar's image as a tourist destination and becomes essential although not the primary element of tourism development. A field survey method with a ground check approach was conducted to obtain spatial data. Observation and interviews of halal and non-halal culinary entrepreneurs are carried out afterward. This research found the development of halal food stalls in the city of Denpasar grow significantly even though the dynamics of society also emerge. The existence of halal stalls supports tourism in terms of providing facilities and services. This supports the image of a tourist destination.
\end{abstract}

Key words: halal food stall, geo spatial, tourism, Hinduism, minority

* $\quad * \quad * \quad * \quad * \quad *$

\section{INTRODUCTION}

The tourism industry is one of the state's economy booster especially for developing countries like Indonesia. The Tourism Ministry stated that Indonesia's tourism industry contributed to 5.25\% of the state's Gross Domestic Product (GDP). It took four years for tourism to increase its contribution by 1 percent to $4.25 \%$ in 2015 . This sector's contributions are yet to be optimized, seeing Indonesia's enormous potential in tourism. Thus the government keeps focusing on optimizing tourism sectors including declaring halal destinations and New Bali's ten tourism destinations. From those ten destinations, five of them were claimed as national strategic tourism area with a super-priority status following Toba Lake in North Sumatra, Borobudur Pagoda in Central Java, Mandalika in West Nusa Tenggara, Bunaken in North Sulawesi, and Bangka Belitung. It is hoped that those five destinations can be domestic and international tourists' magnet just as how Bali is.

Based on the statistic from The Central Bureau of Statistic in 2018, Bali is places top in international tourists visit Indonesia with 6.3 million tourists of $38.7 \%$ compared to other places in Indonesia in 2019, followed by Jakarta and Riau Islands. Not so different, domestic tourists to Bali also increased every year with 9.8 million in 2018. A large number of tourists indicated that Bali is still the most favorite tourist destination that offered culture exotism, religion, and a rich legacy. Those elements are found in Balinese daily activities and are controlled by Hinduism (Mastika and Nimran, 2020). The paradox is located in the reality that the majority of Bali (Hindu) citizens are counter-productive by several of Muslim's cultural values and halal status (Wilson and Liu, 2010). Behavior norms and Islamic teaching are often imagined as contradicting West societies' norms or other Non-Muslim societies (Henderson, 2006). This is understandable as the strength of culture and religions greatly affected perception and individuals' behavior toward themselves and others (Delener, 1994; Essoo and Dibb, 2004; Zamani-Farahani and Musa, 2012).Thus, it's no wonder that many Bali citizens are against the planning of Bali as one of the halal tourist destinations in 
Indonesia. There are many reasons for those rejections. On one side, those who agree with halal tourism can understand the high potential of halal tourism that is not yet optimized following Muslims awareness of the significance of halal tourism (Battour et al., 2021; Battour and Ismail, 2016; Junaidi, 2020; Kamran and Omran, 2018; Markham, 2014; Rahim and Shahwan, 2013). CresentRating.com reported that Muslim tourists contribute to $12.3 \%$ of the total world tourists spending (Rosnan et al., 2015). On the other hand, halal tourism high potential in Indonesia is hegemonic that threatened the existence especially of Hindu as a minority in Indonesia but is embraced majorly by Bali citizens (Makhasi and Rahimmadhi, 2020). The hegemony of halal tourism that continues to be echoed also presents political identity from the non-Muslim majority areas in Indonesia to reject or counterhegemony over halal tourism that wants or will be developed in its territory. This momentum comes following the 2019 Presidential and Vice Presidential elections which certainly raises the tension of political identity in each region. The objection of halal tourism also occurs as Bali has a deeply rooted image as cultural tourism based on local wisdom with its Tri Hita Karana philosophy. Etymologically, the philosophy has the meaning of three sources of happiness that can be achieved if there is a harmonious relationship with the three elements of the universe, namely God, the natural environment, and humans (Pitana, 2010).

Although rejections are expressed greatly by the Bali province government and civil society, halal tourism in a form of halal places to eat is easy to locate especially in Denpasar city as the capital city of Bali province. The question arises of where and how can a halal labeled place to eat in Denpasar city, Bali province can be massively present and survive amid Denpasar citizens whom the majority are Hindu or as many as $64 \%$ of other religions (Statistik, 2010). The extent to which the spatial distribution of halal culinary in Denpasar, especially South Denpasar district can fulfill the desires of Denpasar citizens. Many current pieces of research on halal tourism focus on destination marketing and successful halal tourism model development (Al-Ansi and Han, 2019; Battour et al., 2010; Carboni et al., 2014; Kamran and Omran, 2018; Khan and Callanan, 2017; Najib et al., 2020; Pamukcu and Sariisik, 2020; Ryan, 2016). There are still limited publications that discuss the development of halal tourism in the attributes of halal places to eat in the middle of non-Muslim communities along with its spatial distribution. It is hoped that this spatial distribution can provide input especially for Bali tourist destinations marketers also to explore and find out the origins of these dining places based on Micro, Smal, and Medium Enterprises (MSMEs) in Denpasar.

\section{METHOD}

This research used a qualitative methodology to explore halal's MSMEs restaurant in non-Muslim majority locations. The research is located in Denpasar city. As the capital city of Bali province, Denpasar can represent Bali's condition though not generalizing other cities/regencies in Bali. From four districts in Denpasar city, South Denpasar was chosen as the specific location for research. Data collection was conducted through a field survey with a ground check approach to collect spatial data on dining places in South Denpasar. After spatial data are collected, the data are categorized into two main categories which are consumable for all and consumable only for non-Muslims. These categories are only for MSMEs actors of halal dining places. Post categorizing and spatial data processing, observation, and interviews are conducted with 16 halal culinary entrepreneurs. This technique was used to explore the depth of how those halal culinary entrepreneurs can arrive and work in Denpasar to develop their businesses as inseparable aspects of Bali's tourism.

\section{LITERATURE REVIEW}

\section{Islamic tourism, Halal Tourism and Halal Food}

The concept of halal tourism and the concept of Islamic / Sharia tourism often encounter ambiguity in meaning and are often confused (Hamza, 2012; Neveu, 2010). The two concepts are often used interchangeably as if they both have the similar and often the same meaning (Battour et al., 2014; Henderson, 2009; Jafari and Scott, 2014; Stephenson, 2014; ZamaniFarahani and Henderson, 2010). The fundamental difference between the concept of Islamic tourism and halal tourism lies in the objective perspective (Aziz et al., 2015). Islamic tourism focuses more on activities that have specific goals and motivations spiritually and socially based on Islamic Sharia. Meanwhile, Sharia (which comes from Arabic) is a guide as well as the way of life of Muslims in carrying out activities. Addressing halal, it is not only food products but also related to nonfood products such as cosmetics, pharmaceuticals (medicines), leather crafts, fragrances, including services such as banking, entertainment, tourism, and logistics (Rahim and Shahwan, 2013). The wide aspects of halal are creating a wide interpretation of the word halal that is often constructed differently (De Nastiti and Perguna, 2020.). The term halal tourism refers to the practices that are permitted or approved by Islamic law which focuses on supporting economic opportunities from the supply chain in the tourism sector as an effort to meet Muslim needs by providing attributes that are by Islamic Sharia (El-Gohary, 2016). Hence, sharia Islam is very attached to halal tourism. There are many attribute categories in halal tourism ranging from products, services, facilities to environment (Vargas-Sánchez and Moral-Moral, 2019). One of the halal products is in the form of halal food and beverages. According to the Indonesian Ulema Council, halal food and beverages are products that meet the following criteria. First, it does not contain pork and ingredients derived from pork. Second, it does not contain materials that are prohibited by the Islamic sharia, including human organs, feces, blood, and carnivores animals. Third, all halal animals that are slaughtered by complying to the Islamic sharia, and finally all food and drinks that are not intoxicating.

\section{RESULT AND DISCUSSION}

\section{Spatial Distribution of Halal, Non-Halal Stalls and Their Social Settings}

Bali is for Tourism, not Tourism for Bali. "Bali untuk Pariwisata bukan Pariwisata untuk Bali” (Governor of Bali, Ida Bagus Oka, October 1991). Bali has long been considered a tourism window that has a strategic role in the wheels of tourism in Indonesia. Its name is even better known than Indonesia (Picard, 2006). Bali is praised for its rich traditions and local wisdom and has made its culture as a product of tourism. There are many factors of why tourists come to Bali, one of them is 
the strength of destination branding which is considered as capable of motivating and encouraging tourists. This branding was established from the combination of various factors such as price, scenery, weather, friendliness of the people, and including its infrastructure (Coban, 2012; Jamaludin et al., 2012). This destination branding has an impact on increasing tourist visits in all cities/regencies across Bali province. Historically, regencies in Bali originated from kingdoms. Those kingdoms have a character, cultural norms, systems, and governance, including Denpasar city. This city was originated from the Mengwi kingdom and the Badung kingdom in Bali. After being selected as the capital city of Bali province in 1958, Denpasar has continued to develop rapidly from time to time, not only from its infrastructure (physically) but also its citizens' socio-cultural level. Denpasar as the center of education, economy, governance, and business gave a significant effect on population density (Figure 1).

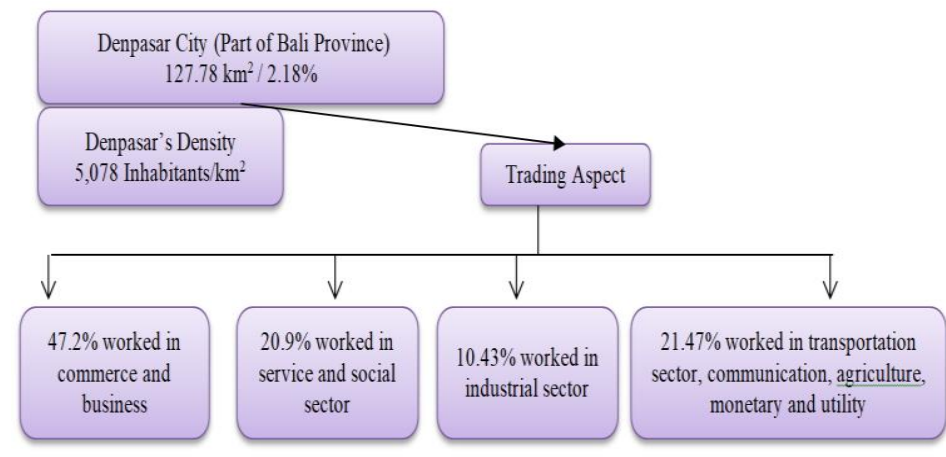

Figure 1. Percentage of Trading Aspect in Denpasar (Source: Central Bureau of Statistics, 2016)

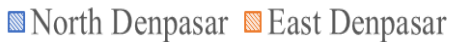

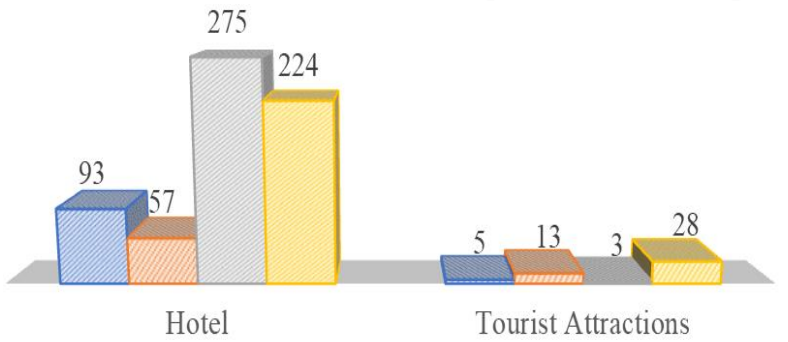

Figure 2. Number of Hotels and Tourist Attractions (Source: Compiled from internet - traveloka.com and google earth imagery)

In 2020, there are 49 tourist attractions supported by 650 hotels (Figure 2). The growth is inseparable from the increase in the number of tourists coming to Bali, especially Denpasar, whether for vacation, business trips, business, family gathering, or enjoying the natural scenery. Of the four districts in Denpasar city, South Denpasar district have the most tourist attraction whether it be natural or artificial compared to other districts. The central governance (Bali Province Governor office) is also located in South Denpasar. This district is also adjacent to Badung regency that has many tourist attractions and hotels compared to its neighboring area. The number of tourist attractions is related to the number of halal dining places in South Denpasar. Even though it is dominated by Hinduism, halal dining places are easily found. For more information (Table 1). This can be seen clearly from the use of the label "halal" or " $100 \%$ halal" in these places. Some use the word "Muslim" as a sign that the owner is a Muslim, and some even use the name of both cities/regencies in Indonesia where the majority of areas are Muslim such as Banyuwangi, Lamongan, Padang, Madiun, Malang, Solo, Bandung including Jakarta. These small-scale actors rely on the assumption that Indonesia is a predominantly Muslim country so their food is automatically halal by simply being labeled "halal" or having the words "Muslim" written on it or using the name of a predominantly Muslim area. "Halal", "Muslim" and the name of the region become their identity which allowed the consumers to find halal food and beverages halal substituting of having a halal certificate.

Table 1. Dining places category in Denpasar (Source: Research primary data)

\begin{tabular}{|l|c|c|}
\hline & Consumable for All & Only for non Muslim \\
\hline South Denpasar & 201 & 55 \\
\hline North Denpasar & 91 & 18 \\
\hline East Denpasar & 158 & 23 \\
\hline West Denpasar & 166 & 27 \\
\hline Total & $\mathbf{6 1 6}$ & $\mathbf{1 2 3}$ \\
\hline
\end{tabular}
attributes arose following the Bali Bombing events, first in 2002 and second in 2005. The incidents claimed many lives and are unforgettable for the Balinese people. This resulting in the reactive and careful responses of Denpasar citizens towards symbols that attributed Islam. However, those who agree with halal tourism with all its attributes believed that halal tourism is an emerging opportunity that has a clear and specific segmentation (Mohsin et al., 2016). Halal tourism is seen as a "new gold" which illustrates the great potential to be developed by looking at the rapidly growing Muslim population around the world (Chandra, 2014). Halal diction has become a paradox, especially within the minority Muslim community area. On one hand, the word halal, taken from Islamic terminology presenting a polemic because it is an adjective of "tourism". Halal tourism is considered to have led to a new definition containing the symbolization of the religion of Islam, which is considered to legalize violence and create disintegration. On the other hand, the diction of halal when it is put as an adjective for "food" or "warung" (stall) is considered as something common, ordinary, and not horrific. This is indicated by the number of dining places and stalls labeled with halal significantly scatter in Denpasar, including in the South Denpasar district (Table 1). The massiveness of halal restaurant is unstoppable and even exceeds the number of non-halal food or food that is only for non-Muslims. Halal dining places are identified by the availability of halal menus according to Islamic sharia, labeling "halal" or "Muslim" which is displayed on the name of the restaurant, or even attributes (symbols) that indicate that the halal food seller is Muslim such as wearing the Hijab for women, writings of " Allah "and" Muhammad "on the walls, or calligraphy that is inscribed with the holy Koran. The halal logo affixed to the restaurant is not a halal logo through official procedures or issued by the official institution, known as the Indonesian 
Ulema Council. But the halal logo is a sign that the food in the restaurant comes from animals that are allowed to be eaten in Islam, such as chickens, cows, goats, and so on. When the restaurant is halal, it can be categorized as "consumable for all". Meanwhile, a restaurant that provides a pork menu either as a main or additional menu is categorized as "only for non-Muslims".

The existence of these dining places supports Denpasar's tourism in terms of providing facilities and services. This sort of facility is very much needed, especially for Muslim travelers to provide them with convenience in finding halal dining places. For some Muslims, practicing Islamic sharia by eating halal food is mandatory and it is the Muslim lifestyle (Rarick et al., 2012). Halal is no longer a label attached to products but it has evolved into a lifestyle. The halal lifestyle trend continues to advance including in tourism. Muslim tourists will try their best in finding halal dining places when visiting Denpasar as it is part of their lifestyle. When one of the components ranging from tourism attractions, accommodation, transportation, infrastructure, facilities provision, and support services does not provide its best services to visitors with varied backgrounds, it will affect the regional destinations image (Govers et al., 2007; Xu, 2010). Bali's destination branding as "The Island of God" is continued to be developed and expressed as an attempt to create societies' trust towards Bali, after the Bali Bombing incidents (Couteau, 2014). A positive destination image will generate word of mouth by tourists on the positive side as well (Snaith and Haley, 1999). The growth of the Muslim and Halal labeling in dining places in Denpasar cannot be separated from the influence of religion and community beliefs (Harahsheh, 2019). This is due to Muslims as a minority in Denpasar, they are unable to arbitrarily choosing a place to eat. They avoid foods that violated Islamic sharia such as pork, dog meat, intoxicating drinks, and others. This halal lifestyle created economic opportunities to open halal dining places. The massiveness of halal dining places also indicates that halal products and services are not only exclusive to the Muslim market (El-Gohary, 2016), but rather creating new opportunities economically and socially, as well as cultural exchanges, and new marketing between Muslim and non-Muslim communities in supporting tourism and tourist destination branding(Wilson et al., 2013). This opportunity is advantageous to many migrants in building "halal" or "Muslim" label businesses, especially in Denpasar.

The market responses are quite positive toward the existence of halal dining places for both Muslims and non-Muslims (Figure 3). Food stalls are not exclusive to Muslims, although are given halal appendages that identified Muslims. Balinese people often eat in halal dining places. They presumed that halal dining places and restaurants provide choices to the public also are considered to have a distinctive taste compared to non-halal food (made from pork). Halal food products are considered attractive to nonMuslim consumers due to satisfaction, sanitation, and health concerns (Stephenson, 2014). On the other hand, for Muslims, the existence of halal food stall is considered as an oasis within majority domination. The main challenge in this economic opportunity is finding equilibrium with the majority without contradicting the teachings of minority Muslims in Bali.
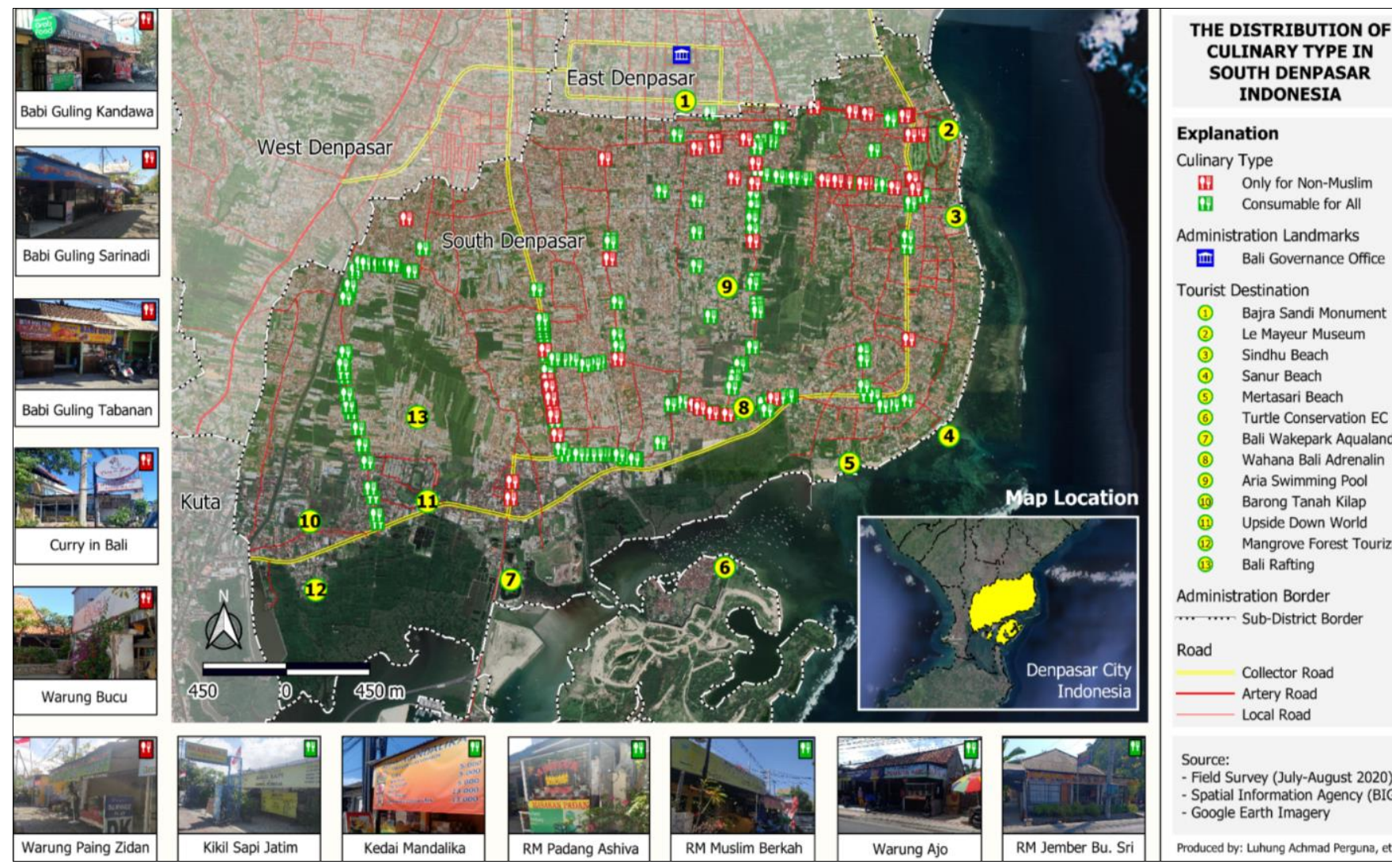

Explanation

Culinary Type

Iit Only for Non-Muslim

Iit Consumable for All

Administration Landmarks

II Bali Governance Office

Tourist Destination

(1) Bajra Sandi Monument

(2) Le Mayeur Museum

Sindhu Beach

Sanur Beach

Sanur Beach
Mertasari Beach

Turtle Conservation EC

Bali Wakepark Aqualand

Wahana Bali Adrenalin

Aria Swimming Pool

Barong Tanah Kilap

Map Location

(11.) Uarong Tanah Kilap

(11) Mangrove Forest Tourizm

Administration Border

... .... Sub-District Border

Road

Collector Road
Artery Road

— Local Road

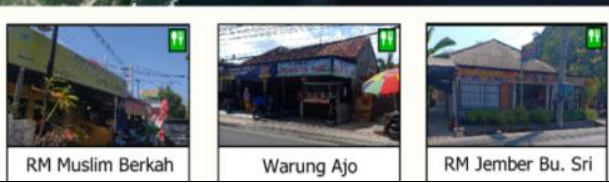

Source:

- Field Survey (July-August 2020)

- Spatial Information Agency (BIG)

- Google Earth Imagery

Figure 3. Distribution of Culinary Stalls in South Denpasar

\section{Halal Culinary: Support or Hinder Tourism}

The availability of halal food and beverages, including halal dining places, is common in Denpasar's tourist destinations. Tourists are given the option to choose types of food both halal and non-halal. In reality, the number of halal culinary delights in Denpasar continued to increase. South Denpasar is the highest district based on the number of MSMEs halal culinary. This 
is understandable as the district has the largest number of tourist attractions compared to the three other districts in Denpasar city. The Bali province central government is also located in South Denpasar District, making the district analogous to sugar which will always be surrounded by ants. Although the district is the largest with halal culinary delights, however, it is relatively far from tourist attractions and central government buildings. The existence of these stalls is mostly circulated in the supporting area of South Denpasar. High land prices, limited business capital, hotel domination, and office buildings are the reasons culinary entrepreneurs opt to open their business in the supporting area. Interestingly, the distribution of these halal culinary stalls is relatively circulated and filled almost all types of roads, from the artery, collector, to local roads.

Geographically, the South Denpasar district is located in the south of the Indian Ocean. In the context of Javanese culture, the South is considered to be mystical, sacred, which is related to magic. Even in some areas in Java Island, the southern part cities/regencies are often neglected than the northern cities/regencies. This neglect and sacredness are often manifested through ritual and cultural expression, which differs from the Northern area. Southern and Northern peoples have a different character. As the South is close to the ocean, the relation with the sacred living is thicker than those of the North. The agricultural communities (North) can work with relatively controlled resources, making their activities much composed. Dependency on something of a metaphysical nature is much lower, is the contrasting reality that occurred in Southern society. They are very dependent on nature and transcendental. The central government and cities in Java Island mostly are located in the North. The fact is that what applies in Java Islands are not in line with Bali Island, especially Denpasar. The southern area of Denpasar literally a more progressive area seeing from its numbers of hotels, halal culinary, and tourist attractions. Although its geographic location is close to the beach, not many of its people are fishermen. The focus of South Denpasar development is on the tourism sector. One of the many tourism sectors is the dining place. Dining places and restaurants are one of the facilities and services that must be available in tourist destinations. The available dining places can be put into consumable for Muslim or consumable only for non-Muslim or consumable for all. Each has different customer segmentation and both support the tourist destination branding effort. In Denpasar, you can easily find non-halal food with visible labels such as $100 \%$ haram, Babi guling (roasted pork); plecing pork satay; and others. Even in Denpasar, there is a very popular place that sells this type of non-halal food with a busy number of visitors. Other than its famous natural tourist destinations and local wisdom, some tourists made the consumption of boiled pork a mandatory destination when visiting Denpasar. On the other hand, Indonesia, which is predominantly Muslim, requires tourist destinations like Denpasar to provide Muslim-friendly dining places. The increasing number of halal culinary delights is proof that Denpasar is a Muslim friendly destination followed by the increasing number of Muslim tourists to Denpasar and Bali. Various dining options also support the selection of holiday destinations. The more diverse the culinary options, the more it will be a tourist destination option (Chaney and Ryan, 2012; Horng and Tsai, 2010). This option is even used as branding in developing a different and attractive identity (Lin, 2009). In Denpasar, diverse food options and segmented is not the main purpose for tourists when visiting Denpasar and Bali. As far as the research results are qualitative in nature, the key elements that make tourists visit Denpasar and Bali are due to its culture, local wisdom, as well as the beauty of its natural scenery. However, without being supported by the availability of halal or non-halal food, efforts to make the branding as friendly in all elements of tourist destinations are difficult to achieve. This confirms previous research that the availability of segmented food does not have a significant effect on overall tourist satisfaction (Mannaa, 2020).

\section{CONCLUSION}

The development of halal tourism continued developing in Indonesia and has become a trend of the global Islamic economic industry. One of the increasing trends is the increasing number of Micro, Small, and Medium Enterprises (MSMEs) attempting to obtain halal labels both officially and non-officially. The upsurge also occurred in Denpasar, Bali Island. Although the society dynamics arose massively from the increase in the number of halal food stalls are due to the traumatic feeling caused by the Bali bombing incidents as well as to promote identity politics, but its existence supports tourism in Denpasar in terms of providing facilities and services. These facilities and services are important to support the image of tourist destinations, especially in the South Denpasar area.

\section{Acknowledgment}

This research was funded by the Malang State University through the 2020 Non-Tax State Revenue (PNPB) fund.

\section{REFERENCES}

Al-Ansi, A., \& Han, H. (2019). Role of halal-friendly destination performances, value, satisfaction, and trust in generating destination image and loyalty. Journal of Destination Marketing \& Management, 13, 51-60. https://doi.org/10.1016/j.jdmm.2019.05.007

Aziz, Y.A., Rahman, A.A., Hassan, H., \& Hamid, S.H. (2015). Exploring the Islamic and halal tourism definition. Hospitality and Tourism 2015, Proceedings of HTC, 139-150.

Battour, M., Battor, M., \& Bhatti, M.A. (2014). Islamic attributes of destination: Construct development and measurement validation, and their impact on tourist satisfaction. International Journal of Tourism Research, 16(6), 556-564. https://doi.org/10.1002/jtr.1947

Battour, M., \& Ismail, M.N. (2016). Halal tourism: Concepts, practises, challenges and future. Tourism Management Perspectives, 19, 150154. https://doi.org/10.1016/j.tmp.2015.12.008

Battour, M.M., Ismail, M.N., \& Battor, M. (2010). Toward a halal tourism market. Tourism Analysis, 15(4), 461-470. https://doi.org/10.3727/108354210X12864727453304

Battour, M., Salaheldeen, M., \& Mady, K. (2021). Halal tourism: Exploring innovative marketing opportunities for entrepreneurs. Journal of Islamic Marketing. https://doi.org/10.1108/JIMA-06-2020-0191

Carboni, M., Perelli, C., \& Sistu, G. (2014). Is Islamic tourism a viable option for Tunisian tourism? Insights from Djerba. Tourism Management Perspectives, 11, 1-9. https://doi.org/10.1016/j.tmp.2014.02.002

Chandra, G.R. (2014). Halal tourism; a new goldmine for tourism. International Journal of Business Management \& Research, 4(6), 45-62. 
Chaney, S., \& Ryan, C. (2012). Analyzing the evolution of Singapore's World Gourmet Summit: An example of gastronomic tourism. International Journal of Hospitality Management, 31(2), 309-318. https://doi.org/10.1016/j.ijhm.2011.04.002

Coban, S. (2012). The effects of the image of destination on tourist satisfaction and loyalty: The case of Cappadocia. European Journal of Social Sciences, 29(2), 222-232.

Couteau, J. (2014). After the Kuta bombing: In search of the Balinese soul. Antropologi Indonesia. https://doi/org/10.7454/ai.v0i70.3454

De Nastiti, N., \& Perguna, L.A. (2020). Konstruksi Konsumen Muslim Terhadap Labelling Halal Pada Produk Kosmetik (Studi Fenomenologi Penggunaan Kosmetik Halal Di Kalangan Mahasiswi Di Kota Malang. Jurnal Analisa Sosiologi, 9(1). https://doi.org/10.20961/jas.v9i1.37671

Delener, N. (1994). Religious contrasts in consumer decision behaviour patterns: Their dimensions and marketing implications. European Journal of Marketing.

El-Gohary, H. (2016). Halal tourism, is it really Halal? Tourism Management Perspectives, 19, 124-130. https://doi.org/10.1016/j.tmp.2015.12.013

Essoo, N., \& Dibb, S. (2004). Religious influences on shopping behaviour: An exploratory study. Journal of Marketing Management, 20(78), 683-712. https://doi.org/10.1362/0267257041838728

Govers, R., Go, F.M., \& Kumar, K. (2007). Promoting tourism destination image. Journal of Travel Research, 46(1), 15-23. https://doi.org/10.1177/0047287507302374

Hamza, I.M. (2012). Islamic tourism: Exploring perceptions \& possibilities in Egypt. African Journal of Business and Economic Research, 7(1), 85-98.

Harahsheh, F. (2019). The effect of cultural dimensions on tourism promotion in Jordan. Management Science Letters, 9(1), 43-52. https://doi.org/10.5267/j.msl.2018.11.001

Henderson, J.C. (2006). Tourism in Dubai: Overcoming barriers to destination development. International Journal of Tourism Research, $8(2), 87-99$. https://doi.org/10.1002/jtr.557

Henderson, J.C. (2009). Islamic tourism reviewed. Tourism Recreation Research, 34(2), 207-211. https://doi.org/10.1080/02508281.2009.11081594

Horng, J.S., \& Tsai, C.T.S. (2010). Government websites for promoting East Asian culinary tourism: A cross-national analysis. Tourism Management, 3l(1), 74-85. https://doi.org/10.1016/j.tourman.2009.01.009

Jafari, J., \& Scott, N. (2014). Muslim world and its tourisms. Annals of Tourism Research, 44, 1-19. https://doi.org/10.1016/j.annals.2013.08.011

Jamaludin, M., Johari, S., Aziz, A., Kayat, K., \& Yusof, A. (2012). Examining structural relationship between destination image, tourist satisfaction and destination loyalty. International Journal of Independent Research and Studies, 1(3), 89-96.

Junaidi, J. (2020). Halal-friendly tourism and factors influencing halal tourism. Management Science Letters, 10(8), 1755-1762. https://doi.org/10.5267/j.msl.2020.1.004

Kamran, H.W., \& Omran, A. (2018). Impact of environmental factors on tourism industry in Pakistan: A study from the last three decades. In The Impact of Climate Change on Our Life, 197-212, Springer. https://doi.org/10.1007/978-981-10-7748-7_11

Khan, F., \& Callanan, M. (2017). The "Halalification" of tourism. Journal of Islamic Marketing. https://doi.org/10.1108/JIMA-01-2016-0001

Lin, Y.C. (2009). Linking local and culinary cuisines with destination branding. In Tourism branding: Communities in action. Emerald Group Publishing Limited https://doi.org/10.1108/S2042-1443(2009)0000001010

Makhasi, G.Y.M., \& Rahimmadhi, M.T.Y. (2020). Ramai-Ramai Menolak Wisata Halal: Kontestasi Politik Identitas dalam Perkembangan Wisata Halal di Indonesia. Jurnal Sosiologi Reflektif, 14(2). https://doi.org/10.14421/jsr.v14i2.1767

Mannaa, M.T. (2020). Halal food in the tourist destination and its importance for Muslim travellers. Current Issues in Tourism, 23(17), 2195-2206. https://doi.org/10.1080/13683500.2019.1616678

Markham, D. (2014). Fluorishing halal tourism sector offers business opportunities. Retrieved November, 14, 2015.

Mastika, I.K., \& Nimran, U. (2020). Destination branding model of an ecological tourism village in Bali, Indonesia. GeoJournal of Tourism and Geosites, 31(3), 1068-1074. https://doi.org/10.30892/gtg.31319-542

Mohsin, A., Ramli, N., \& Alkhulayfi, B.A. (2016). Halal tourism: Emerging opportunities. Tourism Management Perspectives, 19, 137-143. https://doi.org/10.1016/j.tmp.2015.12.010

Najib, M., Sumardi, R.S., Nurlaela, S., \& Fahma, F. (2020). Determinant Factors Of Muslim Tourist Motivation And Attitude In Indonesia And Malaysia. GeoJournal of Tourism and Geosites, 31(3), 936-943. https://doi.org/10.30892/gtg.31301-524

Neveu, N. (2010). Islamic tourism as an ideological construction: A Jordan study case. Journal of Tourism and Cultural Change, 8(4), 327337. https://doi.org/10.1080/14766825.2010.521252

Pamukcu, H., \& Sariisik, M. (2020). Suggestions for standardization of halal tourism in hospitality industry. Journal of Islamic Marketing. https://doi.org/10.1108/JIMA-04-2019-0078

Picard, M. (2006). Bali: Pariwisata budaya dan budaya pariwisata. Kepustakaan Populer Gramedia.

Pitana, I. (2010). Tri Hita Karana-the local wisdom of the Balinese in managing development. In Trends and issues in Global Tourism 2010 (pp. 139-150). Springer. https://doi.org/10.1007/978-3-642-10829-7_18

Rahim, N.F., \& Shahwan, S. (2013). Awareness and perception of muslim consumers on non-food halal product. Journal of Social and Development Sciences, 4(10), 478-487. https://doi.org/10.22610/jsds.v4i10.787

Rarick, C., Falk, G., Barczyk, C., \& Feldman, L. (2012). Marketing to Muslims: The growing importance of Halal products. Journal of the International Academy for Case Studies, 18(1), 81.

Rosnan, H., Osman, I., Nor, N.M., \& Aminuddin, A. (2015). Halal certification: An exploratory study on non-certified restaurants. Advanced Science Letters, 21 (6), 1854-1857. https://doi.org/10.1166/asl.2015.6136

Snaith, T., \& Haley, A. (1999). Residents' opinions of tourism development in the historic city of York, England. Tourism Management, 20(5), 595-603. https://doi.org/10.1016/S0261-5177(99)00030-8

Statistik, B.P. (2010). Indonesia-Sensus Penduduk 2010. Jakarta.

Stephenson, M.L. (2014). Tourism, development and 'destination Dubai': Cultural dilemmas and future challenges. Current Issues in Tourism, 17(8), 723-738. https://doi.org/10.1080/13683500.2012.754411

Vargas-Sánchez, A., \& Moral-Moral, M. (2019). Halal tourism: State of the art. Tourism Review. https://doi.org/10.1108/TR-01-2018-0015

Wilson, J.A., Belk, R.W., Bamossy, G.J., Sandikci, Ö., Kartajaya, H., Sobh, R., Liu, J., \& Scott, L. (2013). Crescent marketing, Muslim geographies and brand Islam. Journal of Islamic Marketing. https://doi.org/10.1108/17590831311306336

Wilson, J.A., \& Liu, J. (2010). Shaping the halal into a brand? Journal of Islamic Marketing. https://doi.org/10.1108/17590831011055851

Xu, J.B. (2010). Perceptions of tourism products. Tourism Management, 31(5), 607-610. https://doi.org/10.1016/j.tourman.2009.06.011

Zamani-Farahani, H., \& Henderson, J.C. (2010). Islamic tourism and managing tourism development in Islamic societies: The cases of Iran and Saudi Arabia. International Journal of Tourism Research, 12(1), 79-89. https://doi.org/10.1002/jtr.741

Zamani-Farahani, H., \& Musa, G. (2012). The relationship between Islamic religiosity and residents' perceptions of socio-cultural impacts of tourism in Iran: Case studies of Sare'in and Masooleh. Tourism Management, 33(4), 802-814. https://doi.org/10.1016/j.tourman.2011.09.003 